Portland State University

PDXScholar

1972

\title{
The Role of Social Work in Genetics Counseling
}

Diane Margaret Plumridge

Portland State University

Follow this and additional works at: https://pdxscholar.library.pdx.edu/open_access_etds

Part of the Social Work Commons

Let us know how access to this document benefits you.

\section{Recommended Citation}

Plumridge, Diane Margaret, "The Role of Social Work in Genetics Counseling" (1972). Dissertations and Theses. Paper 1575.

https://doi.org/10.15760/etd.1574

This Thesis is brought to you for free and open access. It has been accepted for inclusion in Dissertations and Theses by an authorized administrator of PDXScholar. Please contact us if we can make this document more accessible: pdxscholar@pdx.edu. 
THE ROLE. DF SOCIAL WORK

IN GENE.TICS COUNSEL ING

4.

by

DIANE MARGARET PLUMRIDGE

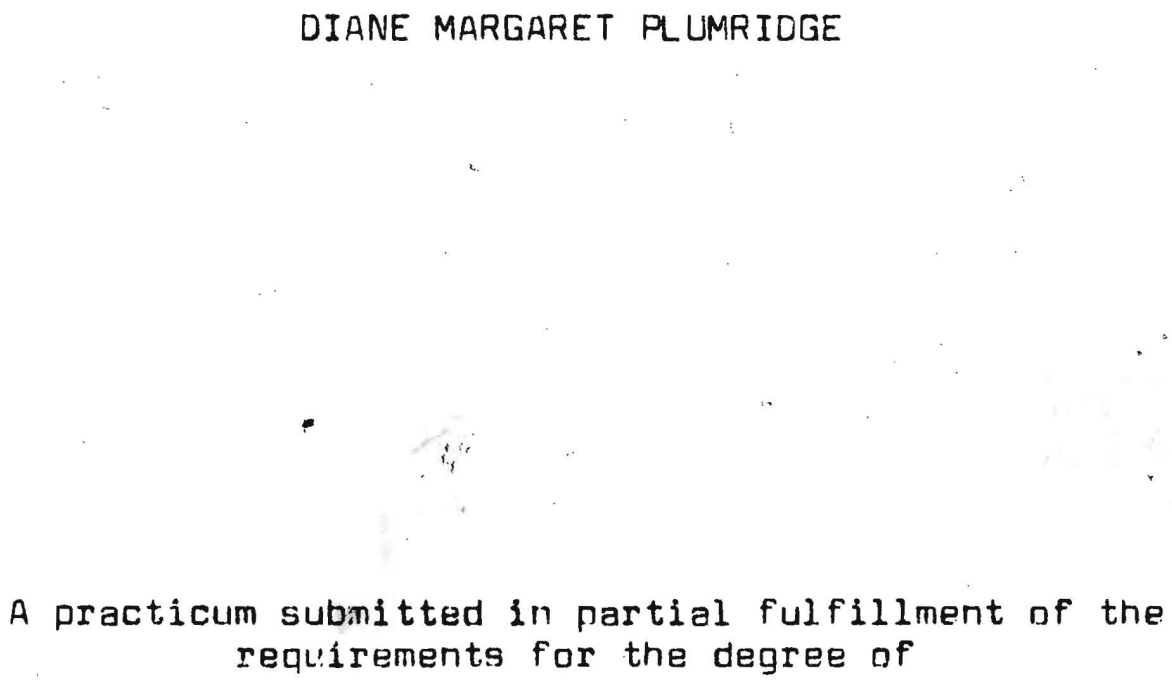

MASTER OF SOCIAL WORK

Portland State University

1972 
TO THE OFFICE OF GRADUATE STUDIES:

The members of the Committee approve the practicum of

Diane Margaret Plumridge presented April 7, 1972.

Jack $\mathrm{H}_{\text {. Hegrenes }}$

B. John Hale<smiles>C1CCCC1</smiles>

APPRDVED:

Gordon Hearn, Dean of School of Social work

April 7, 1972. 
I. Introduction . . . . . . . . . . . 1

II. Historical Goals. . . . . . . . . 5

A. Early Medical Goals . . . . . . . . 5

1. Past

2. Present

3. Future

H. Historical Development of Human Lenetics

1. Early History

2. Establishment of Genetics Clinics in the United States

3. Current Clinics

III. Extended Delivery of Medical Services . •

A. The Social Worker's Role on the Genetics Team . . . . . . . . 9

B. National Survey of Genetics Clinics . . 10

IV. Specific Areas of Sncial Work Expertise . 12

A. Patient Care . . . . . . . . 12

1. Family Planning

2. Girief
a. Crisis
b. Chronic

3. Management
3. ABC's of Care
b. Behavior
c. Finances
d. Sterilization
e. Long Term Care

日. Research . . . . . . . . . . 21

C. Teaching. . . . . . . . . . 21

ن. Summary . . . . . . . . . . . . . 23

Fontnotes . . . . . . . . . . 25

Bibliggraphy . . . . . . . . . . 28

Appendix . . . . . . . . . . . . 31 
AN ABSTRACT OF THE PRACTICUM OF Diane Margaret Plumridge for a Master of Social Work, pregented April 7, 1972.

Title: The Role of Social Work in Genetics Counseling. APPRDVED BY MEMBERS OF THE PRACTICUM COMMITTEE:

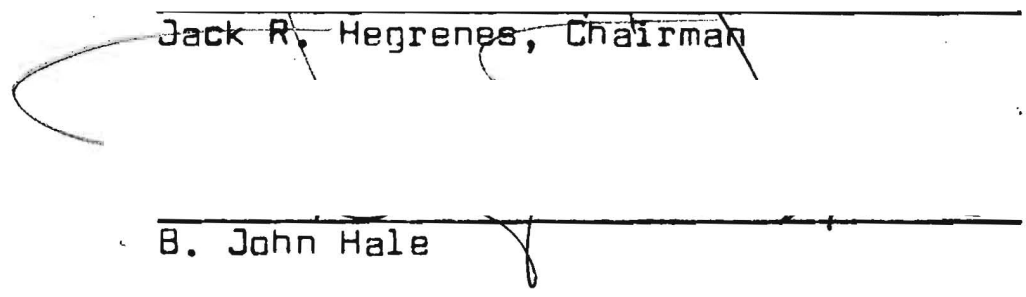

ABSTRACT

The purpose of this practicum is to demonstrate the need for social workers to be employed by Genetics Clinics as a member of the genetics team, the hypothesis being that there is need for social work involvement in the field of medical genetics.

Research was completed through a survey of the jiterature in the fields of: counseling problems in genetic counseling, sacial work invalvement in genetics clinics, the role of nursing in genetic cuunseling, and psychological studies concerning problems of genetic counseling. Literature in these areas was extremely limited. During the summer of 1971, a questionnaire was sent to ninety genetic clinics, requesting information on the role that social work played in these clinics. 
Interviews were held with Or。 Everett Lovrien, co-director of the University of Dregon Medical School Genetics Clinic, Dr. Rohert Koler, director of Genetic Research, University of Dregon Medical School, Mrs. Sue Underwood, Public Health Nurse with the Genetics Clinic, and Dr. Amelia Schultz, research instructor and medical social worker for the clinical Research Center, University of Washington, Seattle, Washington, regarding their opinions concerning the role that social work should play in genetic counseling.

This paper willl incorporate a brief history of genetics and the establishment of genetic counseling clinics, the goals and purposes of a team approach to medical service, a summary of the findings of the questionnaire, and a discussion of the areas where social work could incorporate its own skills and areas of expertise in the clinic into the three major areas of patient care, research, and teaching. 
ACKNOLLEDGMENTS

I wish to extend my thanks to the members of the University of Oregon Medical School, Dr. Everett Lovrien and Mrs. Sue Underwood of the Genetics Clinic Staff, who have shown interest and given encouragement in this project, and to John Hale, Social Worker far the Crippled Children's Division, who compiled and correlated the date from the questionnaires.

A special thanks goes to Dr. Jack Hegrenes, Chairman of my committee, who has spent many hours giving advice and support toward the completion of this project. 


\section{CHAPTER I}

\section{Intraduction}

Perents may carry the potential for their children to be born with an inherited defect which results from the mating of their two cells. Thirty-five thousand years after the advent of man, the study of genetics, a basic discipline of biology, is awakening to the awareness that future generations may be altered by genetic modification. Laboratory and technical advance, however, has to have a contemporary social purpose or it is of no avail. Medical genetics, as an applied subject, is finding itself increasingly involved with the psychosocial problems created by genetic defects, problems which often pose more conflict and pathology than the defect itselfo

Frequently families who are known to social agencies have genetic disorders. Sometimes social pathology is intrinsic to the disease itself, as for example Huntington's Chores, a progressive disease, which has a relatively late manifestation, and one which poses a real threat to the emotional climate of the whole family as they await its onset.

Child placement agencies, child guidance centers, and family counseling agencies deal with the fears and anxieties of parents' j.nabilities to produce and nurture physically, mentally and emotionally healthy children. A healthy self image and self concept of one's own individual germ plasma is one of the vital elements in maintaining the stability of the entire family. Anxiety concerning ane's own reproductive potentiel produces emotional, sexual, and marital strain。

There are an increasing number of inherited disorders associated with mental retardation which are coming to the attention of medical centers, educational systems, and social agencies, 
all of which have invested large amounts in time, energy and money to help each child develop to his full potential.

As a science, genetic counseling is the transmitting of accurate information to indjuiduals, and their families, regarding the possible presence of genetic abnormalities in themselves and assessing the genetic risk of recurrence of these defects in further pregnancies。

The scientific search for the facts and potential implications of human heredity is genetics' chief objective. The supplying of these facts pits the patient's intellect against his emotions. The primary responsibility of the social workers is the mental health of the patient with whom he deals, the social worker being professionally equipped to help the patient weigh the significance of the medical information and to help him integrate the genetic information so that he can make his own decisions for achieving an optimum competence. This involves close collaboration between physician and social worker. Wolfensberger and kurtz write about the dilemma of genetic counseling:

It is more pertinent to the problems of genetic risk assignment than to the handing of parental feelings. Individuals competent to give patients genetic facts are not often competent in the handing of parental dynamics, and may not be sensitive to the fears, irrationalities, etc., associated with belief's about heredity, or to attitudes and conflicts regarding sex and reproduction. On the other hand, those trained in counseling usually lack knowledge about genetics or the techniques necessary for genetic diagnosis. As a consequence, genetic counseling has consisted mostly of recitation of genetic facts to parents and has tended to be isolated from the larger management context. 1

Ideally every large population center should have at least one heredity clinic uhich is regularly open to the public to assure that this counseling is avallable. Every hospital, which maintains a diagnostic clinic of any kind should have same arrangement by which advice on human genetics can be provided. No citizen should be beyond the reach of dependable advice about his personal problems of family heredity. 
A comprehensive model for a genetic counseling service is one which would combine the most advanced laboratory services with a broad spectrum of medical and allied specialists who are available an a consistent basis for consultative evaluation for the individual and his family. This would be supported by professionals skilled in the dynamic aspects of family counseling. These counseling centers should then include as staff members: physicians, geneticists, technicians, nurses, and sncial workers, each discipline containing its own area of expertise. It is through joint sharing among these disciplines that greatest service to the patient may be rendered.

Social workers must make a visible effort to become an integral part of a genetics clinic team. Social workers should not do genetic counseling per se, but there are areas in which they can rightfully and professionally intervene without violating the primary medical responsibility for case management. To date, primary social work contact in these clinics has been through related medical programs, such as for the mentally retarded or multiple handicapped, or for those cases followed for specific genetic diseases, such as hemophilia or cystic fibrosis. 2

The roles and aims of social work are as consistent in genetics as in any other field of medical social work. The primary difference is that the self-concepts of the marital partners and extended family members may be threatened when they learn they not only have produced deviant children, but they themselves are carriers of $a$ defect. Al though there are no new skills in social work practice to be identified as specific to genetics, there is the need for an acquisition of some specialized knowledge and information about genetics in order to apply social work skills.

Research and teaching are two other important areas of endeavor wity which social work may be cancerned. The success of the science of genetic counseling is revealed when research indicates a decrease in genetic disorders. It is through knowledge of interviewing techniques that social work can take an active part in research, thereby helping make this scientific success visible. 
Modern educational methods show an increased inter-disciplinary approach to both learning and teaching. Various health personnel, including social workers, have joint responsibility in both training together and in efficiently and competently dispensing this expanding knowledge to other personnel.

The specific expertise of the social worker then is in patient care, dealing with "that to which the disease is joined," 3 but it is also secondarily found in the areas of research and teaching. 


\section{CHAPTER II}

\section{HISTORICAL GOALS}

Since the seventesnth century medical thought has been dominated by the belief that improvements in health are primarily the function of engineering and technology. 4 Two major themes, prevention and treatment, run through the course of history. Health, in modern sense, grew out of the urgent social need to control epidemic disease in the developing cities during the early days of the Industrial Revolution. The factory mode of production required a healthy and stable work force unharassed by cholera, typhus and other plagues. Control of these diseases was essential to $1 \mathrm{ife}$ as it developed in. America and in the other industrialized nations of the world.

\section{Early Medical Goals}

Medical technology has always preceded healtn care delivery. Nursing and social work are only recently and slowly moving from the position of adjunct to full team membership in the delivery of health care service. Treatment first, and later prevention, has been the concept that has led to the modern delivery of health care services, nursing and medical based social service. Changing views of "health rights" has elicited potential change in the delivery system of health services. Health care and management will eventually move out of the large medical institutions and back into the local community, meaning allied health personnel will have increasing roles of importance in the delivery system.

Today, concern for incipient disease is beginning to take precedence over established illness. The increase in longevity, due to control of infectious diseases, improvement of diet, and application of anaesthesia, has resulted in the major cause of mortality now being based, at least in part, on heredity factors. It has been the 
stimulus which has allowed medical technology to advance into the genetic research field。

Today, diseases of clearly defined genetic origin comprise about six percent of the admissions to pediatric hospitals and another fifteen percent of these admissions are for suspected genetic content. Genetic disease also accounts for a majority of the deaths in pediatric medicine. 5 Mass screening methods are continually allowing more types of genetic disease to be recognized early in life, creating increased health benefits from early diagnosis and treatment. Allied health services are in increasing demand to facilitate the delivery of these early prevention and treatment programs.

Human genetics, as a science, as an applied subject, and as an area of social concern, extends into antiquity. Fascination with human and plant reproduction as a curiosity can be found in ancient history. According to the theory of Hippocrates (460 $8 \mathrm{C}$ 360 BC), each part of the body produced a substance which was released at copulation into the semen, providing a material basis for the characteristics of offspring. Aristotle ( 384 BC - 322 BC) criticized this theory, his general conclusion being that it was the potential for producing characteristics which was inherited, not the characteristics themselves.6 Charles Darwin (1809 - 1882) reflected upon the modification of the species, but it was the Augustinian monk, Gregor Johann Mendel (1882 - 1884) who, crossing varieties of garden peas, discovered the first laws of heredity which subsequently led to the science of genetics.?

William Bateson, $E_{n}$ lish biologist, coined the term "genetics" in 1902 to designate that brancy of biology which deals with inherited resemblances and differences between individuals and with the evolution of all living things. In a paper published in 1902 he promised his fellow biologists that

an exact determination of the laws of heredity will probably work more change in man's outlook of the warld and in his power over nature than any other advance in natural knowledge that can be clearly foreseen. 
With the exception of the atom, he is very nearly accurate. Genetic research started slowly and then accelerated. Ninety percent of the genetic information available today has been uncovered since the end of Warld War II. 9

Genetic counseling goes back to the Babylonian Talmud, the record of rabbinical discussions compiled 2,000 years ago. A case history presented concerned four sisters in Lower lalilee who all bore male children. The sons of three sisters all died during the circumcision. When the fourth sister asked a rabbi whether the procedure was advisable for her son, she was told not to have the baby circumdised. The rabbis were well aware that circumcision occasionally caused dangerous hemorrhages, it having been noted in the Talmud that "there are some families whose blood is loose while in other families it clots." They also recognized that the bleeding was transmitted through the famale because the general principle in these cases was that "sisters establish a presumption." The scholars then launched intio a protracted argument concerning "how many sisters needed to be apparently affected before circumcision was contra indicated." The rabbinical counseling was in accordance with what is now common knowledge concerning the $x$-linked inheritance of the hemophiliac group of bleeding disorders. 10 Historical Development of Human Genetics

The first organized institution in the United States for the study of human heredity was the Eugenics Record Office established in 1910. This became part of the Carnegie Institute in 1918, but its work was later abandoned, and the study of human heredity was relegated to individual research interest with only occasional articles being published dealing with the heredity of particular characteristics. 11 by 1952 there were less than twelve clinics in the United States where counseling was offered, 12 by 1964 there were approximately thirty, 13 and by 1969 the International Directory of Birth Defects Genetics Services listed one hundred fifty-eight units which stated they did genetic counseling. 14 
Today most states are setting up genetic counseling programs under the aegis of maternal and heal th care services. These programs usually develop as units within hospitals and medical facilities。 The ularld Health Organization recommends that eventually genetic counseling centers should be organized in areas where infectious disease and nutrition disorders are being brought under control and an international register of human chromosome anomalies should be available for all physicians. 15

Genetic counseling today fits into the community medicine or public health mold. The cost and administration of providing research and advice in this field should be and is primarily born by the government, just as are other projects that affect mental heal th. 16 


\section{CHAPTER III}

\section{EXTENDEO DELIVERY OF MEOICAL_ SERVICES}

The past ten years have shown an increasing stress on the need for team work in delivery of medical services. Burgeoning medical knowledge, new concepts of comprehensive health care and environmental manipulation mean rapidly changing needs for health manpower in this country.

To most efficiently facilitate delivery of services, not only to individuals but to the broader community, there has been increasing reliance upon the team approach. The tasks of medical care today encompass disease prevention, treatment and the broader field of health maintenance. The tasks of health maintenance by allied medical personnel are not yet clearly defined, but movement toward the common goal of equal access by all persons to health care calls for more and more efficient delivery of this care.

Today most mental heal th professional workers have a good grounding in dynamic psychology and psychopathology and most disciplines are becoming more socially oriented. However, since no one has expertness of knowledge in all fields, sharing of knowledge through team effort is becoming more widely recognized as the accepted approach to the delivery of this care.

The uniderlying problem in facilitating this team approach has, to date, been one of trust. Each specialty has to gain the respect of other occupational groups. This can only be done through proving competence in the specialists' field.

\section{The Social Worker's Role on the Genetics Team}

Genetics teams are primarily medically ariented. They should also have at their disposal child psychiatrists, social workers, psychologists, speech and hearing specialists, and public health nurses.17 The team has a dual responsibility. The first is of 
insuring that the patient and family receive accurate and authoritative information regarding the possible presence of chromosomal or genetic abnormalities in themselves and in their progeny and in assessing the genetic risk of recurrence in further offspring. The second is the availability of sensitive counseling, which takes into consideration the crisis nature of the situation. 18

Interpretation interviews at the University of Nebraska 19 have shown that there is not necessarily a direct relationship between the actual severity of the defect and the degree of emotional upset and disorganization which may appear in the parents. Team members, who do interpretation interviewing, are chosen depending upon the special problems presented by the child and of the specific concerns and anxieties of the parents.

The secret of successful genetic counseling is not only in the accuracy of the information that is relayed to the patient, but it is also in the accuracy of what he hears and understands and how he reacts to this.

National Survey of Genetics Clinics

During the summer of 1971 a mail survey of ninety genetics clinics was made to determine, not only the rale that sacial service played in genetics counseling, but also to determine if there was a trend toward the team philasophy in delivery of care. The clinics were identified from the Birth Defects Genetic Services International Directory. ${ }^{20}$ This directory listed forty-six genetics facilities as having social services attached. Of these forty-six clinics polled, twenty responded. Of the twenty responses, thirteen indicated they had a social worker employed by their clinic.

Forty-four more queries were then mailed on a random basis to units listed as offering genetic counseling. Thirty usable replies were recsived and, of these thirty, thirteen reported the presence of a social worker on their staff。"

* See appendix for a complete compilation of statistics. 
It is significant to note that only about fifty percent of the responses indicated they had a social worker on their staff (even though some clinics did have access to social service from some other source.)

There was confusion in the determination between what constituted a team, whether it was medical or inter-disciplinary; however, twenty of the twenty-six units with social workers called their units a team approach to delivery of service and another three reported a trend toward a team philosophy, indicating that almost ninety percent of these clinics considered themselves team oriented. Ten of the twenty-four of the non-social work genetic units reported that their units were teams.

There were thirty social workers employed by the twenty-six units. Interestingly enough, the smaller the counseling staff, the greater chance there was that one staff member was a social worker。

Twenty-three of the thirty social workers had an MSW, MA or MS degree. Five had a BA or BS, one a DSW, and one an MPH。

Only one clinic (one which hired one and one-half workers) reparted employing a sacial worker for over forty hours a week. Fifteen units reported staff members spent twenty or less hours a week working for a clinic。

This total picture indicates that social work is in the process of making a small, but growing impact on genetic counseling services. The goal now should be to make the need for expanded social service usable through continuing efforts in the areas of patient care, research and teaching. 
CHAPTER IV

\section{SPECIFIC AREAS OF SOCIAL WORK EXPERTISE}

Thomas Mann in an essay on Nietzsche said, "Sickness is something purely schematic. What is important is that to which it is joined, that in which it fulfills itself." It is "that to which it is joined"and "that in which it fulfills itself" which is the particular diagnastic concern of the social caseworker. ${ }^{21}$ It is these problems, that to which the disease is attached, which social work must address itself。

of the three areas, patient care, research and teaching, where social work can make a contribution in genetic counseling, the area of patient care is the most diversified. But first, in any field, social work must know what it is attempting to do and what are its strengths and its limitations.

Social work is successful, depending upon the conditions presented, the powers in the client, the kind of problems presented, and the aim of the goals. 22

Helen Perlman says, "Social casework focuses upon the 'case', the single individual unit in society, whether that unit is one person or a family. The focus is upon the small but vital arena social-psychological problems are encountered by the living human being, are felt, struggled with, sweated out, wept or bled over, and are capitulated to or overcome."23

The social worker's knowledge and skill must be used to give a realistic appraisal of the persons to be helped, to know what they want, how amenable they are to help, and what resources are available for extending help.

\section{Patient Care}

The following areas of patient care partially cover some of the problems where these criteria may apply. 
Family planning is the first area of significance where the patient must resolve his own emotional confusion before he can make a vadid decision regarding producing further children. For clarification it should be noted that in this instance family planning is used within the framework of genetic sounseling. Actually the broad objective of family planning is directly related to the needs of the family to control its size so that the family can better provide its members with the benefits of society in all spheres: economically, socially, educationally, psychologically, and physiologically. For purposes here, genetic sounseling is confined to , those families who have identifiable or known genetic defects。 24

The opportunity for family units to participate in a therapeutic program, which allows a free expression of family anxieties and overall problems, is what distinguishes this type of genetic counseling from the traditional mathematical probability approach. 25

Emotional and sexual maladaption is bound to occur if the lack of a solution to the decision as to whether to bear further children is not fully resolved.

The understanding of genetic risks is fairly simple. For instance, in an autosomal dominant inheritance, a single mutant gene is sufficient to cause a given clinical effect. The chance that a child of an affected person will inherit the mutant gene is fifty percent. Affected offspring will in turn transmit the mutant gene to half of their children, whereas children not receiving the gene will not transmit it to any of their progeny.

In recessive inheritance, both parents must carry the mutant gene and the risk is twenty-five percent with each new pregnancy. 26 Analogy to dice throwing can be used to explain this, recalling that chance has no memory and that the risk remains the same with each pregnancy, regardless of whether all or no affected children have been born earlier.

Every couple carries the risk of one to two percent that a given pregnancy may end in some type of abnormality. All genetic risks must be added to this figure. 27 
Many counselors feel that it is best to have both family members available to receive the genetic information together. The same information can be received in a positive or negative manner. For instance, there is a difference in stating that there is a ten percent chance of having an abnormal birth, instead of stating that there is a ninety percent chance of producing a nornal child. For some parents a ten percent chance may be very high, while in others a fifty percent risk may be considered good news. 28

It has been found that parental reactions are not necessarily in proportion to the news received. A fairly high risk may not deter some parents from having another child if the condition is a very severe one and leads to death of the affected child in early childhood. However, a disease causing prolonged invalidism or mental retardation with resulting financial and social strain, as well as emotional strain, may present stronger hesitation towards reproduction.29

Studies show that, despite the anxieties caused by the genetic defect, most parents are left to their own resources to deal with their problems. 30

Two sides of the same coin; blame and guilt, are problems which must be resolved as they affect their concepts of their self and their spouse, concepts which must be healthy as they are vital to good parental practices. Resolutions of these inner attitudes will allow parents to arrive at an acceptable decision regarding further pregnancies. It is the task of social work to assist parents jointly to arrive at their own decisions by helping them to work through these conflicts.

In addition to knowing the genetic risks of recurrence in further pregnancies and to making a decision based upon rational thought, the patients' interest also extends to the risk of their normal children having affected offspring. Therefore, this becomes a total family problem of concentric proportion, bringing in for attention grandparents, aunts, uncles, and cousins, each with their own fears, ignorances, and feelings of self worth. 
It is of ten apparent that parents are carriers of a genetic defect upon production of their first affected child.

Studies have related the theory of grief and mourning to mothers of defective infants. There is extensive literature on the subject of the crisis of parental reactions to these traumatic births. At any time a painful diagnosis is made parents must adjust their thinking and beihelped through the important steps of disbelief, feeling of loss, feelings of guilt or blame, and reconciliation to the limitations of the child. If the child is diagnosed at birth, the mather must not only grieve the loss of her fantasized and longed for infant, which represents herself and other loved objects, but must also relate to the new baby in a meaningful way. 31 When a baby is born with an obvious defect, the parents should be seen as soon as possible after delivery. Pragmatic experience followed by theoretical rationale has shown that brief casework treatment, rationally directed and purposefully focused at a strategic time is mare effective than more extensive help given at a period of less emotional accessibility。 32

The diagnosis of a genetic defect in a child is of ten inter preted as a crisis of varying proportions to the family members. The state of crisis in which the individual or family finds itself is the result of the stress surrounding the diagnosis and may be manifested by expressions of tension, anxiety, shame, guilt, or hostility. There may also be cognitive confusion. The stress may or may not become a major crisis, depending upon the individual's capacity to cope with or master the problem that has been presented to him.

Studies in crisis intervention indicate that the longer a person goes without being seen by a helping person, the more guarded and better defended he will be against his initial anxiety. Something happens to his accessibility, which makes it more difficult to work with him at a later date. 
Since the acute phase of a crisis does not go on indefinitely, each family or individual will push itself to achieve a new equilibrium. Whether this new equilibrium is heal thy or pathological again depends not only upon the individual strength of each family member but upon what help is available to them when they are most able to utilize it. 33

Often the news concerning a defective child is so painful that everything and every one connected with the giving of the information seems unpleasant to the family. Therefore, the person who gives the family the distressing news is not the one who should counsel the family. This means the social worker should be in a position to be accessible to a family following diagnosis.

Focus at this time should be on the present problem with a fairly active and direct approach. It is a time when it is necessary to help parents strengthen their own ego through helping to lower their tension, anxiety or guilt, to help their intellectual mastery of the problem through further explanation and clarification, and if necessary to give advice when indicated. 34

Parents who suffer from a handicapped child, whether it be mentally or physically limited, may suffer from chronic sorrow throughout their lives. The reality faced by the parent of a retarded child is such as to justify this sorrow. The problems and worries of raising a normal child are compensated by knowledge that ultimately the child will become a self sufficient adult. In contrast, however, the parents of a defective child will be burdened by demands and dependency as long as they, or the child, live. 35

Many factors such as parents' personality, ethnic group, religion, and social class influence the intensity of the sorrow and how it is manifested. Knowledge of these factors will be paramount in indicating how a social worker will proceed in dealing with the family in crisis. For example, Anglo-5axon parents feel the need to "keep a stiff upper lip," which should not be construed as lack of depth of feeling. 
Dr, because guilt is an important religious concept and is handled somewhat differently by the major religions, religious background should be considered as a factor in parental adjustment. Catholics can be more accepting than non-Catholics to genetic defects in themselves and others, as their religious faith explicitly absolves them from a sense of personal guilt in the birth of a defective child. 36

It has been found that what parents require at a time of crisis, both at the time of diagnosis and at stressful points throughout life, is, beyond knowledge of the facts, an opportunity to ventilate and clarify their feelings and to receive support for the legitimacy of the feelings they are expressing. Continuing attention to the maintaining of their ego strengths, clarification, and advice will be necessary at various times throughout their life.

Managing a retarded or handicapped child starts at birth. A great deal of the social worker's contact with the family depends upon the time and circumstinces at which the family was given the diagnosis and told the genetic nature of the problem. Some may have known the facts for some time and had time to adjust to the idea, while others may have learned recently and may still be suffering from shock, in which case the situation is treated as a crisis as previously discussed。

There are sensitive times, however, of which all staff should remain cognizant, times not much different than those reached by normal children. Help, judiciously given at various times of stress, ameliorates the chance of avoiding a major crisis at a later date.

During the extended years of babyhood, parents need help with the ABC's of baby care, helping them with daily management of eating, walking, and toilet training, giving support and practical advice in these areas as needed. A five-year old, who functions on a one year level is not as charming as a nne-year old at the same level. Without support and help parents may become exhausted and want to surrender their responsibility for awhile to others. 
An example of how a modicum of help would have prevented a mother's final almost total disintegration is shown in the following case history:

Mrs. Thomas, forty-twa years old, ADC mother was referred to Genetics Clinic for her five-year-ald Down's Syndrome child, Ruthie. Ruthie, the youngest of nine children, was diagnosed as Down's at birth, but neither she nor her mother had been seen (except for emergency medical care) by anyone knowledgeable about Down's since birth. When Mrs. Thomas was seen at the clinic, she was deeply depressed, grossly overweight, and asking for "my baby to be put sometuhere where they can help her. I can't keep her anymore." In spite of the fact that Mrs. Thomas was an adequate and loving mother and had successfully raised eight other children, her feelings of inadequacy in her inability to cope with her daughter were overwhelming and the only solution she could see was placing her child in an institution.

Because of this mother's total mental and emotional exhaustion, Ruthie was placed in a local institution for a limited time. While she was there, Mrs. Thomas was seen by a social worker on a weekly basis. This was not only for counseling and support concerning her depression and sense of inadequacy, but also for educational purposes. Mrs. Thomas did not know what Down's Syndcome was, but had been told that Ruthie's problem was her fault because thirty-seven was too old to be having children. She did not know what to expect from her child and had not thought she would progress beyond the infant level. By the age of five the child was highly mobile and completely out of her mother's control.

Ruthie was able to learn more than her mother had anticipated and she was helped by the child care staff to teach her daughter a few skills of daily living that would help make life more tolerable when she returned home.

This mother's five-year sense of isolation, inadequacy, and guilt might not have erupted into a critical situation if she had had some contact with concerned other persons throughout the years.

The behavior problems of handicapped children may be a source of frustration for concerned parents, who must walk a tight line between.giving their children physical protection and at the same time refraining from making them psychological invalids.

Hemophilia, a congenttal chronic illness characterized by excessive bleeding, is a sex-linked recessive gene which is transmitted by females, but which primarily affects males. The problems 
of protecting active little boys from normal childish romping and exploration and at the same time allowing them to grow and socialize, imposes a heavy burden upon the self restraint and psychological maturity of parents and other family members. 17

The problem of behavior is further complicated if the child is retarded and the teaching methods used instinctively and successfully with other children in the family aren't successful with the retarded child. Parents may need help in resolving some of their feelings. that may inhibit the handling of their child in the best way to allow his maximum growth within the bounds of safety.

Finances are always a concern to families who may have extended expenditures over a number of years. Dccasional loss of the wage earner's salary due to clinic visits, baby sitting, transportation, special schouling, possible nursery or nursing care, all ascend beyond the average family's insurance policies and the scope of Crippled Children's Services in various states. Knowledge of resources within the state by the social worker may help many families with the very realistic problem of coping on a day to day level in obtaining services which will make life easier.

Voluntary or involuntary sterilization may be a problem as a child reaches adolescence. The pros and cons of this have been, and are today being, argued.

Dregon Revised Statutes, Section 435.305 1969, reads, "A person may be sterilized by appropriate means upon his equest and upon the advice of a physician licensed by the State Board of Medical Examiners." This makes the derision regarding voluntary sterilization the decision and responsibility of each individual adult.

Involuntary sterilization is a more complex problem and is coming under increasing criticism. Oregon Revised Statutes, Section 436.070 1969, states that sterilization as a protective measure shall be made with the purpose in view of avoiding the procreation of children:

a) who would have an inherited tendency to mental retardation or mental illness; or 
b) who would become neglected or dependent children as a result of the parent's inability, by reason of mental illness or mental retardation, to provide adequate care. The focus remains on improvement of the gene pool and, with increasing discoveries of genetic causes for various defects, genetic counselors will have a greater role in this field.

In these enlightened days of personal and sexual freedom, the consequences of sterilization are not generally understood. A study at Cornell University in 1970 revealed gross ignorance, not only about contraceptive techniques, but also about sterilization, among its undergraduates, graduates and faculty。 38 It is ndt unreasonable to suppose then that the rest of society is equally ignorant.

With adequate and perhaps extensive counseling for the patient, or the guardian or parents of the patient, decisions may be reached for the patient's best advantage.

Plans for a child after the death of the parents is an area of particular anguish. It is possibly more difficult to ask extended family members to assume the responsibility for a handicapped child who becomes adult than it is to have that adult die at an early age himself. Even when financial support is not a major issue, parents find it is difficult to ask others to assume what they feel to be their responsibjlity. Patients may call the genetic clinic even though their request is not within the specific responsibility of that facility. A knowledge of local resources and an ability to relate quickly and to give the support necessary when needed will expedite many a family's ability to continue to function to the height of their capabillities.

Family planning, grief, and problems of management are only three of many areas of concern for social work in the problems of patient care. Some, such as family planning, are more clearly within the definition of genetic counseling, while management is more generic to medical social work in general. Again, however, it is the problem to which the disease is attached that is the special expertise of social work. 


\section{Research}

The major goal of Oregon's Genetics Clinic is to provide service to the population of the State of Oregon. The purpose of the 1964 grant from the Children's Bureau was, through genetic counseling, to decrease the frequency of genetic disorders. A patient's decision regarding his unborn children should be made an the basis of correct information and full knowledge of the consequences of producing further progeny. 39

It is the responsibility of the patient to implement the clinic's recommendations. Success or failure of the clinic's primary purpose will be in the research completed determining, a) If the parents understand the information they were given, and b) what decision regarding further pregnancies they made on the basis of the information given.

A study concerning these tur questions has been completed in London, a study which showed positive responses to these two queries plus confirmation that the risks given were on the whole accurate. 40

The first genetic clinic in the British Isles was established in 1946. The total of 438 couples, researched for the project, were visited by twr social workers, both employed by the clinic, three to ten years following the original consultation. Research of this retroactive nature, as well as possible longitudinal studies can be a continuing method for improving patient care, not anly in Dregon's Genetic Clinic but in any clinic which most wishes to make visible its success.

\section{Teaching}

Teaching within a team setting in a medical facility, teaching of other paramedical personnel, and teaching of social workers in other agencies, are all areas where social work can make active contribution.

The education and training of all health workers is changing and there is going to be a continuing need to produce personnel in 
all levels of health delivery services in general and genetics clinics in particular. An inter-disciplinary approach to learning and teaching should combine the resources and knowledge of all health and health-related fields into an integrated and productive excerience for the student. Students in the fields of medicine, dentistry, nursing, psychology, and social work should study together to learn the values and contributions of each profession. Respect for competencies and talents of other professions will maximize efficiency in delivering the health care.

The resources and knowledge of all these fields will also be reflected in the concept of team teaching. Social work should be an active part in both learning and teaching in this team setting. As stated before, various disciplines now are more aware of the psycho-social dynamics of health; but there is a continuing need for social and behavorial sciences to keep health care warkers oriented to human perceptions, needs and problems, and any student entering the field of health care must be aware of the implications of emotional factors related to physical illness. 41

Other agencies and members of health and social service teams must also have access to new and expanding medical knowledge to best facilitate their own delivery care. A social worker in a genetics team can be valuable in working with outside community agencies who rely upon the specialized medical services for their knowledge and expertise, knowledge which in turn facilitates their ability to work with their clients in helping them to manage their own problems on a daily basis.

Parent education is an entirely different area for exploration. Parents of children with genetic defects may be able to use either a group educational experience, one which helps them better to understand their child's special needs, or a group which will help them to fulfill their own needs, through exploring their own feelings of inadequacies, doubts, and fears. Whether the focus is education on a cognitive or emotional level, the coordinator of such an effort should be experienced in the area of dealing with graup interactions and dynamics. 


\section{CHAPTER V}

\section{SUMMARY}

Research and counseling in the field of genetics retreats into antiquity. Today, laboratory and technical advances continue to strive for social purpose and medical genetics, as an applied subject, finds itself increasingly involved with the psychosocial problems which are crsated by genetic defects. As mass screening and continuing discoveries allow even more genetic diseases to be recognized,there will be an increasing demand for allied health personnel to facilitate delivery of health services by giving continuing assistance to the public with relevant prevention and treatment programs.

Successful genetic caunseling combines a close collaboration between physician and social warker. This allows for as precise as possible dispensing of mathematical probabilities of genetic risk for future progeny of any couple, within an atmosphere which allows free expression of family anxieties and overall problems. Studies show that, to date, despite the anxieties caused by a genetic defect, most parents are left to their own resources to deal with their problems and primary social work contact in genetic clinics has been through related medical programs, such as mental retardation, hemophilia, or oystic fibrosis. At the sane time an informal mail survey has indicated that sacial wark, as a member of an inter-disciplinary team, is in the process of making a small but growing impact upon genetic counseling services. The goal now should be to make the need for expanded social service visible through continuing efforts in the areas of patient care, research and teaching.

Successful genetic counseling should be a team effort, medical counseling being dedicated to the dispensing of as accurate information as medically oossible within a climate conducive to the 
patient's greatest receptivity where the social work counseling deals with the problems to which the disease is attached, thereby helping the client cope with the genetic information on both a cognitive and emotional basis, insuring his greatest adaptability。

He can also use his interviewing techniques and skills for research. The goal of genetic counseling is to decrease the frequency of genetic disorders and it is only through research this scientific success can be confirmed。

Lastly, social work can help teach other para medical disciplines and other social anency workers the general psychosocial dynamics of medical social work and how it specifically applies to the field of genetic counseling.

As a recognized discipline of the genetics team, social work then can be of value to patients, to research and to other disciplines. 


\section{FOOTNOTES}

1. Schild, Sylvia, "Genetic Counseling as Part of a Mental Retardation Service: Implications for Social Work Practice," THE SOCIAL WORKER AND FAMILY PLANNING, p. 77.

2. Ibid. p. 76 .

3. Perlman, Helen Harrís, "Classroom Teaching of Psychiatric Social Work," AMERICAN JOURNAL DF DRTHOPSYCHIATRY, pp. 306-315.

4. Mckeown, Thomas, "A Sociological Afproach to the History of Medicine," MEDICAL HISTORY, p. 342.

5. Clow, Carol, et al. "Management of Hereditary Meta milic Diseases," THE NEW ENGLAND JDURNAL OF MEDICINE。p。 1292.

6. Sturtevant, A. H., A HISTORY OF GENETICS, Chapter 1, "Before Mendel," pp. 1-16.

7. Ibid., pp. 1-16。

8. Beadle, George and Muriel, THE LANGUAgE of LIFE, Chapter 1, p. 1.

9. "Clinical Genetics Gain Notice," THE JOURNAL DF THE AMERICAN MEDICAL ASSOCIATION。

10. Ibid. "Clinical Genetics."

11. Dice, Lee R., "Heredity Clinics: Their Values for Public Service and for Research," AMERICAN JOURNAL OF HUMAN GENETICS, pp.9-11.

12. Ibid., pp.9-11.

13. Wittson, Cecil and Cohen, Richard, "A Multidisciplinary Approach to Genetic Counseling," NEBRASKS Site MEDICAL JOURNAL, p. 469.

14. BIRTH DEFECTS GENETIC SERVICES INTERNATIONAL DIRECTORY, Second Edition, September, 1969. 
15. "Genetic Counseling: Third Report," WHO Technical Report Series,) MENTAL RETARDATION ABSTRACT, p。60。

16. Op. cit., Dice, Lee, p. 11-13.

17. Op. cit., wittson, p. 469 。

18. Ibid., p. 470 .

19. Ibid., p. 470。

20. Op. cit., BIRTH DEFECTS GENETIC SERVICES INTERNATIONAL DIRECTORY, 1969.

21. Perlman, Helen Harris, "The Role Concept and Social Casework: Some Explorations," THE SOCIAL SFRVICE REVIEW, p. 19.

22. Perlman, Helen Harris, "Can Casework Work?", THE SOCIAL: SERVICE REVIEW, p. 437 .

23. Ibid., p. 437-438。

24. Schild, Sylvia, "The Challenging Opportunity for Social Workers in Genetics," SOCIAL WORK, pp.23-24。

25. Tips, Robert Lo, et al, "Caenetic Counseling," EUGENICS QUARTERL $Y, P .237$.

26. Motulsky, Arno and Hecht, Frederick, "Genetic Prognosis and Counseling," AMERICAN JOURNAL OF OBSTETRICS AND GYNECOLOGY, PP. 1227-1237.

27. Ibid., p. 1237 .

28. Ibid., p. 1237 .

29. Ibid., p. 1238 .

30. Dp. cit., Schild, "Genetic Counseling as Part of a Mental Retardation Service," p. 77.

31. Kennedy, James, "Maternal Reactions to the Birth of a Defective Baby, SOCIAL CASELORK, July, 1970, p. 411 。

32. Rapaport, Lydia, "Crisis Oriented Short Term Casewark," THE SOCIAL SERVICE REVIEW, p。 34.

33. Ibid., p. 37.

34. Inid., p. 39. 
35. Qlshansky, Simon, "Chronic Sorrow: A Responst to Having a Mentally Defective Child," SOCIAL CASEWORK, p. 192.

36. Zuk, G. H., "The Religious $F_{a}$ ctor and the Role of Guilt in Parental Acceptance of the Retarded Child," AMERICAN JUURNAL DF MENTAL DEFICIENCY," pp.139-140.

37. Katz, Alfeed, "Some Psychosocial Problems in Hemophilia," SOCIAL CASEWDRK, p. 322.

38. E1snor, Thomas, et al., "Population Control, Sterilization and Ignorance," SCIENCE.

39. Lovrien, Everett, M. D., Co-Director Genetics Clinic, University of Oregon Medical School, Crippled Children's Division, Interview September 2, 1971.

41. Kroepsch, Robert, et al., "Heal th Manpower: Adapting in the 70's, Education and Training." pp. 15-17. 


\section{BIBL IOGRAPHY}

Beadle, George and Muriel, THE LANGUAGE OF LIFE, Anchor Books, Doubleday \& Co., Inc., Garden City, New York, 1967.

BIRTH DEFECTS GENETIC SERVICES INTERNATIONAL DIRECTORY, SECOND EDITION, September, 1969, Gergsma, Daniel and Lynch, Henry T., editors. Published by The National Foundation March of Dimes.

Carter, C. D.; Roberts, J. A.; Fraser; Evans, K. A。; Buck, A. R。, "Genetic Clinic, A Follow-up", THE LANCET, Vol. I, \#7693, February 6, 1971 。

"Clinical Genetics Gain Notice," THE JOURNAL. QF THE AMERICAN MEDICAL ASSOCIATION, Vol。213, No. 13, September 28, 1970.

Clow, Carol; Reade, Terry; Scriver, Charles, "Management of Hereditary Metabolic Diseases," THE NEW ENGLAND JOURNAL OF MEDICINE, June 10, 1971。

Dice, Lee R., "Heredity Clinics, Their Values for Public Service and for Research," THE AMERICAN JOURNAL OF HIJMAN GENETICS, Vol. 4, No. 1, March, 1952.

Eisner, Thomas, et al., "Population Control, Sterilization and Ignorance," SCIENCE, Vol. 167, No. 3817.

Gardner, Lytt I., "Genetic Counseling," ENDOCRINE AND GENETIC DISEASES OF CHILDHCOD, W. B. Sanders, Philadelphia, 1969.

"Genetic Counseling": Third Report, (WHO Technical Report Series \#416,) Geneva, Switzerland, 1969, MENTAL RETARDATION Abstract, Vol。 8, No. 1, Jamuary 3, 1971.

Herndon, C. Nash, "Heredity Counseling," EUGENICS QUARTERLY Vol. 2, 1955.

Kallman, Franz J., "Human Genetics as a Science, as a Profession, and as a Soclal Minded Trend of Orientation," AMERICAN JOURNAL OF HUMAN GENETICS, Vol. 4, 1952. 
Kallman, Franz J., "Psychiatric Agpects of Genetic Counseling," AMERICAN JOURNAL OF HUMAN GENETICS, Vol。 $8,1956$.

Katz, Alfred, "Some Psychosocial Problems in Hemophilia," SOCIAL CASEWDRK, Vol。40, No。6, June, 1959.

Kennedy, James F., "Maternal Reactions to the Birth of a Defective Beby," SOCIAL CASEWORK, Vol.51, No. 7, July, 1970.

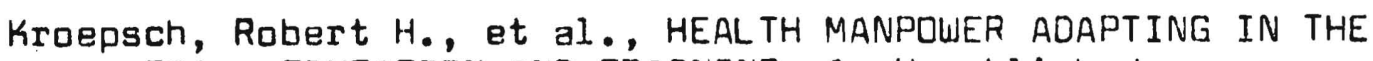
70's, EDUCATION AND TRAINING, An Unpublished paper prepared for the 1971 National Health Forum held in San Francisco, March 14-16, 1971.

Mckeown, Thomas, "A Sociological Approach to the History of Medicine," MEDICAL HISTORY, Vol. 14, No. 4, Octaber, 1970.

Motulsky, Arno and Hecht, Frederick, "Genetic Prognosis and Counseling," AMERICAN JOURNAL OF OBSTETRICS AND GYNECDLDGY, Vol. 90, No。7, Part 2, December, 1964.

Neser, William B., and Suddereth, Grace B., "Genetics and Casmwork," SOCIAL CASEWORK, Vol.46, No. 1, January, 1965.

New, Peter Kong-Ming, "An Analysis of the Concept of Teamwork," COMMUNITY MENTAL HEALTH JOURNAL, Vol. 4, No. 2, 1968.

Olshansky, Simon, "Chronic Sorrow: A Response to Having a Mentally Defective Child,"SOCIAL CASEWORK, Val.43, No. 4, April 1962.

Perlman, Helen Harris, "Can Casework Work," THE Social SERVICE REVIEW, Val. 42, No. 4, December, 1968.

Perlman, Helen Harris, "Classroom teaching of Psychiatric Sncial Work," AMERICAN JOURNAL OF DRTHOPSYCHIATRY, Vol. 19, April, 1949 。

Perlman, Helen Harris, "The Role Cancept and Social. Casework: Some Explorations," THE SOCIAL SERVICE REVIEW, Vol 36, No. 1, March, 1962。

Rapaport, Lydia, "Crisis Driented Short Term Casework," THE SOCIAL SERVICE REVIEW, Vol. 41, No.1, March, 1967.

Reed, Sheldon C., "Human Factors in Genetic Counseling," NATIONAL FOUNDATION MARCH OF DIMES, HUMAN GENETICS, (Eirth Defects, Original Article Series, Vol. 4, Na。 6) New, York, New York, 1968, pp.105-109. MENTAL RETARDATION ABSTRACTS, No。2, April. 6, 1970 
Roberts, J. A. Fraser, AN INTRODUCTION TO MEDICAL GENETICS, Dxford IJniversity Press, London, New York, Toronto, 1970.

Schild, Sylvia, "Counseling with Parents of Retarded Children Living at Home," SOCIAL WORK, Vol。9, No. 1, January, 1964.

Schild, Sylvia, "Genetic Counseling as Part of a Mental Retardation Service: Implications for Social Uork Practice," THE SOCIAL WORKER AND FAMILY PLANNING, Based on the Proceedings of the 1969 Annual Institute for Public Heal th Social Work, 1970.

Schild, Sylvia, "The Challenging Opportunity for Social Workers in Genetics," SDCIAL WORK, Vol. 11, No。 2, Aprid, 1966.

Schultz, Amelia, "The Impart of Genetic Disorders," SOCIAL WORK, Vol. 11, No. 2, April, 1966.

Stevenson, Alan; Davison, Clare; Dakes, Michael, GENETIC COUNSEL ING, J. B. Lippíncott Company, Philadelphia, 1970.

Sturtevant, A. H., A HISTORY OF GENETICS, Harper and Row, Publishers, New Yark, 1965.

Tips, Robert L.; Meyer, Donald; Perkins, Audree, "Genetic Counseling," EUGENICS QUARTERLY, Vol。9, No. 4, December, 1962.

Tips, Robert L., and Lynch, Henry T., "Genetic Counseling in a Team Setting," NATIONAL FOUNDATION MARCH OF DIMES HUMAN GENETICS, (Birth Defects Original Article Series, Vol. 4, No. 6), New York, New York, 1968, MENTAL RETARDATION ABSTRACT No.2, April 16, 1970.

Tips, Robert; Smith, George s.; Lynch, Henry T.; McNutt, C. Wallace, "The Whole Farnily Cancept in Clinical Genetics," AMERICAN JOURNAL OF DISEASES OF CHILDREN, Vol. 107, No. 1, 1964.

wittson, Cecil, and Cohen, Richard, "A Multidisciplinary Approach to Genetic Counseling," NEBRASKS STATE MEDICAL JOURNAL, September, 1965.

Zuk, G. H. "The Religious Factor and the Role of Guilt in Parental Acceptance of the Retarded Child," AMERICAN JOURNAL OF MENTAL DEFICIENCY, Vol. 64, No。 1, 1959-1960. 


\section{INTERVIEWS}

Dr. Amelia Schultz, Ph.D., MSW, Social Worker, C.linical Research Center and Research Instructor, Division of Medical Genetics, Department of Medicine, University Hospital, University of Washington, Seattle, July 20, 1971.

Mrs. Sue Underwood, Public Health Nurse, Genetics Clinic, University of Oregon Medical School, Crippled Children's Division, August 13, 1971.

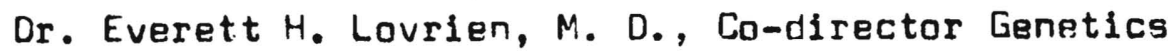
Clinic, University of Dregon Medical School, Crippled Children's Division, September 2, 1971.

Dr. Robert Koler, M: D., Director of Genetic Research, University of Oregan Medical School, Crippled Children's Division, January $14,1972$. 


\section{APPENDIX}

d. What is the size of your professional genetics staff? *

\begin{tabular}{|c|c|c|c|c|c|c|}
\hline $\begin{array}{l}\text { Number of } \\
\text { staff members }\end{array}$ & $\begin{array}{l}\text { Clinics } \\
\text { social } \\
\text { number }\end{array}$ & $\begin{array}{l}s \text { with } \\
\text { workers } \\
\text { percent }\end{array}$ & $\begin{array}{l}\text { Clinic: } \\
\text { social } \\
\text { number } \\
\end{array}$ & $\begin{array}{l}\text { wi thout } \\
\text { workers } \\
\text { percent }\end{array}$ & $\begin{array}{l}\text { Total } \\
\text { number }\end{array}$ & $\begin{array}{l}\text { Total } \\
\text { percent }\end{array}$ \\
\hline $1-3$ & 12 & 52 & 9 & 39 & 21 & 45 \\
\hline $4-6$ & 6 & 26 & 13 & 57 & 19 & 41 \\
\hline $9-10$ & 3 & 13 & 1 & 4 & 4 & 9 \\
\hline $10+$ & 2 & 9 & 0 & & 2 & 4 \\
\hline N. $A_{0}$ & 3 & - & 1 & - & 4 & - \\
\hline Total & 26 & 100 & 24 & 100 & 50 & 99 \\
\hline
\end{tabular}

2. a) Do you have a social worker attached to your clinic? b) If so, how many?

Number of

queries

90

Number of Clinics

$1 / 2$ social worker

1 social worker

$11 / 2$ social worker

2 social workers

Total
Number of

responses

50
Number of positive responses

26

Number of social workers

2

20

2

$\frac{2}{2}$

26
20

2

4

4

30 
3. How many total staff hours do the social warkers spend in genetics related activities each week?

Number of hours per week $2-4$

$$
5-8
$$$$
9-10
$$$$
11-20
$$$$
21-40
$$$$
41+
$$$$
\text { N.A. }
$$

Total
Number

7

3

2

3

3

1

?

26
Percent 37

16

11

16

16

5

101

4. What degree does the sacial warker hold?

\begin{tabular}{lcc} 
Degree & Number & Percent \\
\hline BA-BS & 5 & 17 \\
MSW & 18 & 60 \\
MA-MS & 5 & 17 \\
DSW & 1 & 3 \\
MPH & 1 & 3 \\
Ph.D & D & 0 \\
& 30 & 100
\end{tabular}

Total 
5. What are the general duties of the social worker?

Duties

social history

obtaining pedigrees

crisis intervention

assisting in genetic counseling

referral source

family counseling

family planning

medical management

educational planning

treatment planning

other*
Number

21

$8 \quad 31$

17

3

23

18

9

3

9

7

7
65

Percent

81

12

88

69

33

12

33

30

30

*other: research, training other disciplines, field instructors, ongoing therapy, parent education groups, community education.

6. If there is no social worker, or interdisciplinary team, which discipline handles social. work problems?

\begin{tabular}{lcc}
\multicolumn{1}{c}{ Discipline } & Number & Percent \\
nospital social service & 10 & 42 \\
geneticist or M. D. & 4 & 17 \\
nurse & 4 & 17 \\
other agencies & 1 & 4 \\
not handled & 1 & 4 \\
not ansugered & 4 & 17 \\
Total & 24 & 100
\end{tabular}

